\title{
Study of the environmental and individual factors of autoimmune diseases in the microregion of Águas Formosas - Minas Gerais State, Brazil
}

Estudo dos fatores ambientais e individuais das doenças autoimunes na microrregião de Águas

Formosas-Minas Gerais, Brasil

Estudio de los factores ambientales e individuales de las enfermedades autoinmunes en la microrregión de Águas Formosas - Estado de Minas Gerais, Brasil

Received: 03/22/2021 | Reviewed: 03/28/2021 | Accept: 03/31/2021 | Published: 04/11/2021

Dilceu Silveira Tolentino Junior

ORCID: https://orcid.org/0000-0003-2435-7576 Federal University of the Valleys of Jequitinhonha and Mucuri, Brazil E-mail: dilceujunior@bol.com.br

Sandra Bertelli Ribeiro de Castro ORCID: https://orcid.org/0000-0002-5535-0919

Federal University of Juiz de Fora, Brazil E-mail: bertelli.ribeiro@ufff.edu.br

Ana Carla Amorim

ORCID: https://orcid.org/0000-0001-6136-8456 Federal University of the Valleys of Jequitinhonha and Mucuri, Brazil E-mail: anacarlaamorim04@gmail.com

André Lopes Frisso

ORCID: https://orcid.org/0000-0003-2399-1903 Federal University of the Valleys of Jequitinhonha and Mucuri, Brazil E-mail: frissoandre@gmail.com

João Victor Leite Dias

ORCID: https://orcid.org/0000-0002-7367-3826 Federal University of the Valleys of Jequitinhonha and Mucuri, Brazil

E-mail: joao.dias@ufvjm.edu.br

Alessandra de Paula Carli

ORCID: https://orcid.org/0000-0002-7956-8947 Federal University of the Valleys of Jequitinhonha and Mucuri, Brazil E-mail: alessandra.pcarli@ufvjm.edu.br

Caio César de Souza Alves

ORCID: https://orcid.org/0000-0001-9765-8527

Federal University of the Valleys of Jequitinhonha and Mucuri, Brazil E-mail: caio.alves@ufvjm.edu.br

\begin{abstract}
Autoimmune diseases lead to numerous limiting conditions. Their incidence and prevalence are known to be affected by several factors; and there is an absence of data in areas of economic vulnerability. The aim of this study was to access the epidemiological profile of autoimmune diseases in the public health system of the microregion of health of Águas Formosas, and to evaluate possible factors involved in the development of these diseases. This was an epidemiological study with a cross-sectional, survey-type, descriptive and exploratory. All patients were selected according to the inclusion criteria, and individual interview was conducted during home visits to apply a sociodemographic questionnaire with 20 variables associated with autoimmune diseases. In this study, it was observed that the municipalities of Machacalis, Umburatiba and Crisólita exhibited prevalence of autoimmune diseases above 90 cases per 10,000 of the population, and the other municipalities showed prevalence between 50 and 60 cases. In the microregion, a total of 407 cases of autoimmune diseases were observed, distributed in 24 different diseases, with a general prevalence of $673.69 / 100,000$ of the population. Hashimoto's Thyroiditis, Graves' Disease, Vitiligo, Rheumatoid Arthritis, Psoriasis, Type 1 Diabetes Mellitus and Systemic Lupus Erythematosus, represent $47 \%$ of the cases. This was the first study that addresses the prevalence of autoimmune diseases in the microregion. The lack of registration or diagnosis is a factor that needs to be overcome in new studies to improve the knowledge of autoimmune diseases in this region.
\end{abstract}

Keywords: Prevalence; Autoimmune; Incidence; Low income. 


\begin{abstract}
Resumo
As doenças autoimunes levam a várias condições limitantes. Sabe-se que sua incidência e prevalência são afetadas por vários fatores; e há uma ausência de dados em áreas de vulnerabilidade econômica. O objetivo deste estudo foi acessar o perfil epidemiológico das doenças autoimunes no sistema público de saúde da microrregião de saúde de Águas Formosas, e avaliar os possíveis fatores envolvidos no desenvolvimento dessas doenças. Trata-se de um estudo epidemiológico de corte transversal, do tipo survey, descritivo e exploratório. Todos os pacientes foram selecionados de acordo com os critérios de inclusão, sendo realizada entrevista individual em visita domiciliar para aplicação de questionário sociodemográfico com 20 variáveis associadas a doenças autoimunes. Neste estudo, observou-se que os municípios de Machacalis, Umburatiba e Crisólita exibiram prevalências de doenças autoimunes acima de 90 casos por 10.000 habitantes, e os demais municípios apresentaram prevalências entre 50 e 60 casos. Na microrregião, foram observados 407 casos de doenças autoimunes, distribuídos em 24 doenças diferentes, com prevalência geral de 673,69 / 100.000 na população. Tireoidite de Hashimoto, Doença de Graves, Vitiligo, Artrite Reumatoide, Psoríase, Diabetes Mellitus tipo 1 e Lúpus Eritematoso Sistêmico representam $47 \%$ dos casos. Este foi o primeiro estudo que abordou a prevalência de doenças autoimunes na microrregião. A falta de registro ou diagnóstico é um fator que precisa ser superado em novos estudos para aprimorar o conhecimento das doenças autoimunes nessa região.
\end{abstract}

Palavras-chave: Prevalência; Autoimune; Incidência; Baixa renda.

\begin{abstract}
Resumen
Las enfermedades autoinmunes conducen a numerosas condiciones limitantes. Se sabe que su incidencia y prevalencia se ven afectadas por varios factores; y hay una ausencia de datos en áreas de vulnerabilidad económica. El objetivo de este estudio fue acceder al perfil epidemiológico de las enfermedades autoinmunes en el sistema de salud pública de la microrregión de salud de Águas Formosas, y evaluar posibles factores involucrados en el desarrollo de estas enfermedades. Se trata de un estudio epidemiológico de tipo transversal, tipo "survey", descriptivo y exploratorio. Todos los pacientes fueron seleccionados de acuerdo con los criterios de inclusión y se realizó una entrevista individual durante las visitas domiciliarias para aplicar un cuestionario sociodemográfico con 20 variables asociadas a enfermedades autoinmunes. En este estudio se observó que los municipios de Machacalis, Umburatiba y Crisólita exhibieron prevalencias de enfermedades autoinmunes por encima de 90 casos por 10,000 de la población, y los demás municipios mostraron prevalencias entre 50 y 60 casos. En la microrregión se observaron un total de 407 casos de enfermedades autoinmunes, distribuidos en 24 enfermedades diferentes, con una prevalencia general de 673,69 / 100.000 habitantes. Tiroiditis de Hashimoto, Enfermedad de Graves, Vitiligo, Artritis Reumatoide, Psoriasis, Diabetes Mellitus Tipo 1 y Lupus Eritematoso Sistémico, representan el 47\% de los casos. Este fue el primer estudio que aborda la prevalencia de enfermedades autoinmunes en la microrregión. La falta de registro o diagnóstico es un factor que debe superarse en nuevos estudios para mejorar el conocimiento de las enfermedades autoinmunes en esta región. Palabras clave: Prevalencia; Autoinmune; Incidencia; De bajos ingresos.
\end{abstract}

\title{
1. Introduction
}

The autoimmune diseases are characterized by loss of immunological tolerance to self-antigens, displaying several limitations conditions (Yang et al., 2018; Rose, 2017). Although autoimmune diseases were initially considered uncommon, the effects of these diseases on mortality and morbidity contributed to highlight the importance of these diseases (Bogdanos et al., 2012). Studies show that 3 to $5 \%$ of the worldwide population is affected by autoimmune diseases (Bogdanos et al., 2012; Cooper \& Stroehla, 2003; Jacobson et al., 1997; Rose, 2017; Yang et al., 2018; Roberts \& Erdei, 2020).

The incidence and prevalence of autoimmune diseases are known to be affected by age, gender, ethnicity, geographic location, genetic background and behavioral factors. However, the way that these factors directly influence the development of these diseases remains unknown (Khan \& Wang, 2020; Mak \& Tay, 2014; Milo \& Kahana, 2010; Shukla et al., 2018; Ulmanen et al., 2005; Wahren-Herlenius \& Dorner, 2013).

Studies show that different factors may influence the prevalence of autoimmune diseases in specific areas or countries. Multiple sclerosis, for example, is a demyelinating autoimmune disease of the Central Nervous System that is more prevalent in Europe due to environmental characteristics. However, some of the diseases are also prevalent in countries of Latin America, including Brazil, and some of these differences in the prevalence seem to be influenced by the solar display or parasite infections (Correa et al., 2016; Jackson et al., 2018; Krawczak et al., 2017; Milo \& Kahana, 2010; Moroni et al., 2012).

National studies were carried out by addressing the prevalence of one or more autoimmune diseases in different 
Brazilian regions. A high prevalence of autoimmune diseases as Hashimoto thyroiditis, Sjögren's Syndrome and inflammatory myopathies is observed in a study of familial autoimmunity and poliautoimmunity in patients in the central-west Brazil (Horimoto et al., 2016). In some cases the diseases were also associated with the presence of systemic sclerosis. Another study shows a prevalence of $20 \%$ of Hashimoto thyroiditis in 56 patients with systemic sclerosis (Costa et al., 2014).

National studies show the prevalence of alone or associated autoimmune diseases; however, there is a lack of data to show the proportion of autoimmune diseases in low income areas such as the Mucuri Valley mesoregion, specifically the microregion of health of Águas Formosas - Minas Gerais State. In this context, the present study aimed to know the epidemiological profile of autoimmune diseases in the public health system of the microregion of health of Águas Formosas, and to evaluate the possible environmental factors involved, in the expectancy to subsidize the adoption of health promotion, prevention and recovery.

\section{Methodology}

The project was approved by the Research Ethics Committee of the Federal University of the Jequitinhonha and Mucuri Valleys under registration CAAE:57185316.4.0000.5108 and authorized by the Regional Health Superintendent of Teófilo Otoni and by the Municipal Health bureau of the councils that make up the study. This is an epidemiological study of a quantitative approach with a cross-sectional, survey-type, descriptive and exploratory (Koche, 2011; Ludke \& Andre, 2013; Yin, 2015, Zangirolami-Raimundo et al., 2018).

The research was carried out in the public health system of the Microregion of Águas Formosas, located in the northeast of Minas Gerais state. The microregion has an estimated total population of 60,413 inhabitants (IBGE, 2016), with an approximate 4,150,700 km² of area; and is composed of eight cities: Águas Formosas, Bertópolis, Crisólita, Fronteira dos Vales, Machacalis, Pavão, Santa Helena de Minas and Umburatiba. Before data collection, a study was carried out in the medical records in the 26 units of primary health care in the Microregion, from January to December 2016, searching for patients that were diagnosed with autoimmune diseases.

The inclusion criteria in this study were man and woman raised in the Microregion of health of Águas Formosas, have been confirmed diagnostic of autoimmune disease, not less than 7 years old. These interviews were carried with the authorization of the subjects and the signing of the Informed Consent Form or Informed Assent Form. The control group was constituted of the individuals healthy, raised in the Microregion of health of Águas Formosas. All the patients were selected according to the inclusion and exclusion criteria.

After the medical records survey of the cases with a positive diagnosis for autoimmune diseases, an individual interview was conducted during home visits by trained nurse, that applied the sociodemographic questionnaire with behavioral variables associated at autoimmune diseases such as: vaccinated against hepatitis B, odontological surgical procedure, physical or psychological trauma, surgical procedures, used hair tints or other chemicals agents by inhalation, treated water consumption, practiced physical exercises and cow milk consumption before 6 months of age.

The collected data were analyzed in BioEstat software version 5.0. The description of the categorical elements was performed by simple logistic regression. Then, multiple logistic regression was used to estimate the odds ratios between the variables. Variables with $\mathrm{p}<0.05$ were significantly associated.

\section{Results}

In the epidemiological survey of autoimmune diseases in the health microregion of Águas Formosas - Minas Gerais Brazil, it was observed that the municipalities of Machacalis, Umburatiba and Crisólita exhibited the prevalence of 
autoimmune diseases above 90 cases per 10,000 of the population, and the other municipalities showed prevalence between 50 and 60 cases (Figure 1A).

Figure 1. Prevalence of autoimmune diseases in the health microregion of Águas Formosas - Minas Gerais State - Brazil. (A) Prevalence of autoimmune diseases in the municipalities that constitute the microregion. (B) Prevalence of different autoimmune diseases in the microregion.

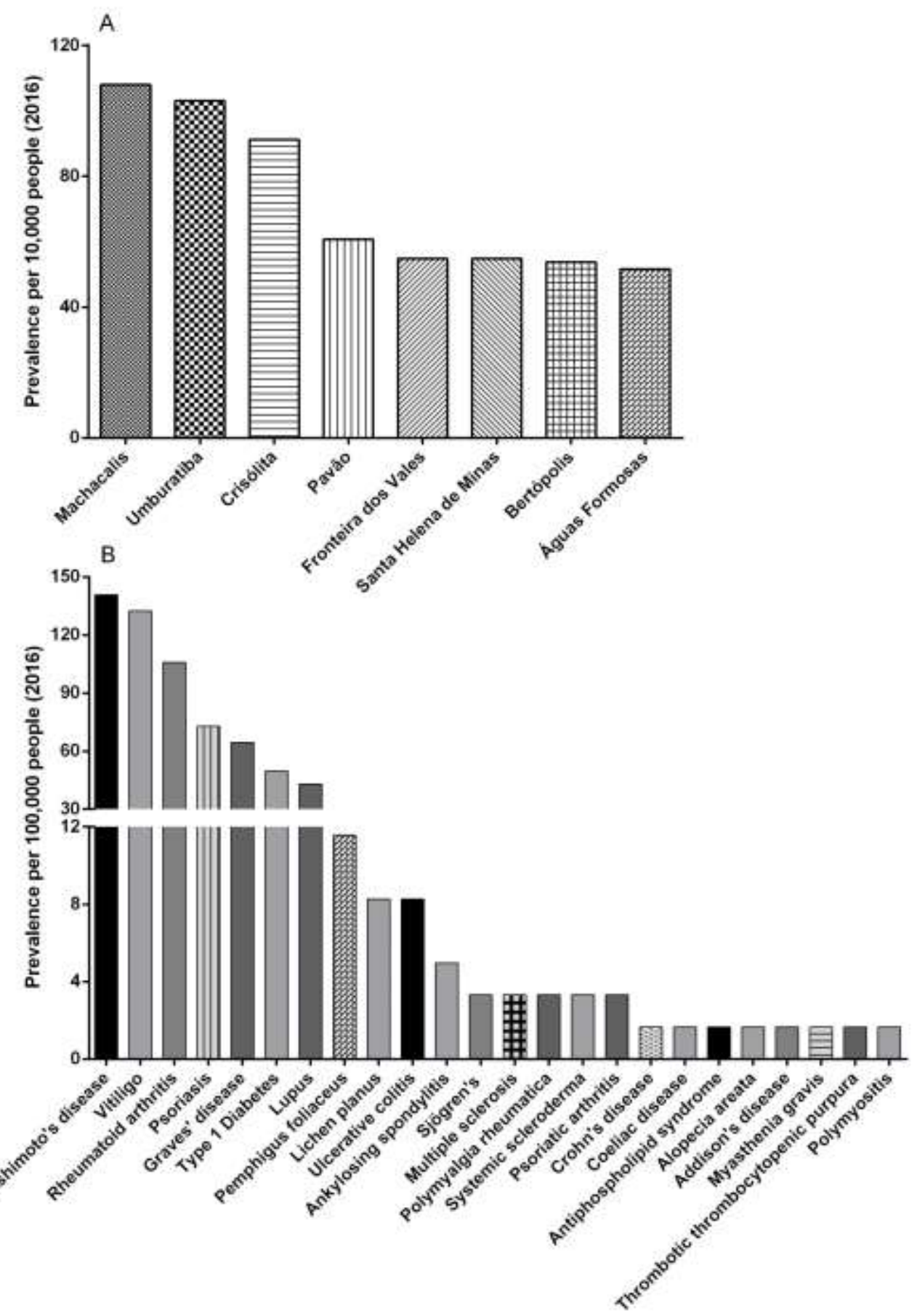

Source: Authors.

In the present study 407 cases of autoimmune disease were observed, distributed in 24 different diseases, with a 
general prevalence of 673.69 cases per 100,000 of the population, distributed among the municipalities of the region (Figure 1). In the analysis of the sociodemographic profile of autoimmune disease patients, a higher percentage of prevalence was found in women, people in productive age, of whom $87 \%$ were older than 30 years, and of brown-skinned group (Table 1).

Table 1. Distribution of the autoimmune diseases and sociodemographic characteristics of the patients in the municipalities of Águas Formosas microregion $-\mathrm{MG}-2016$.

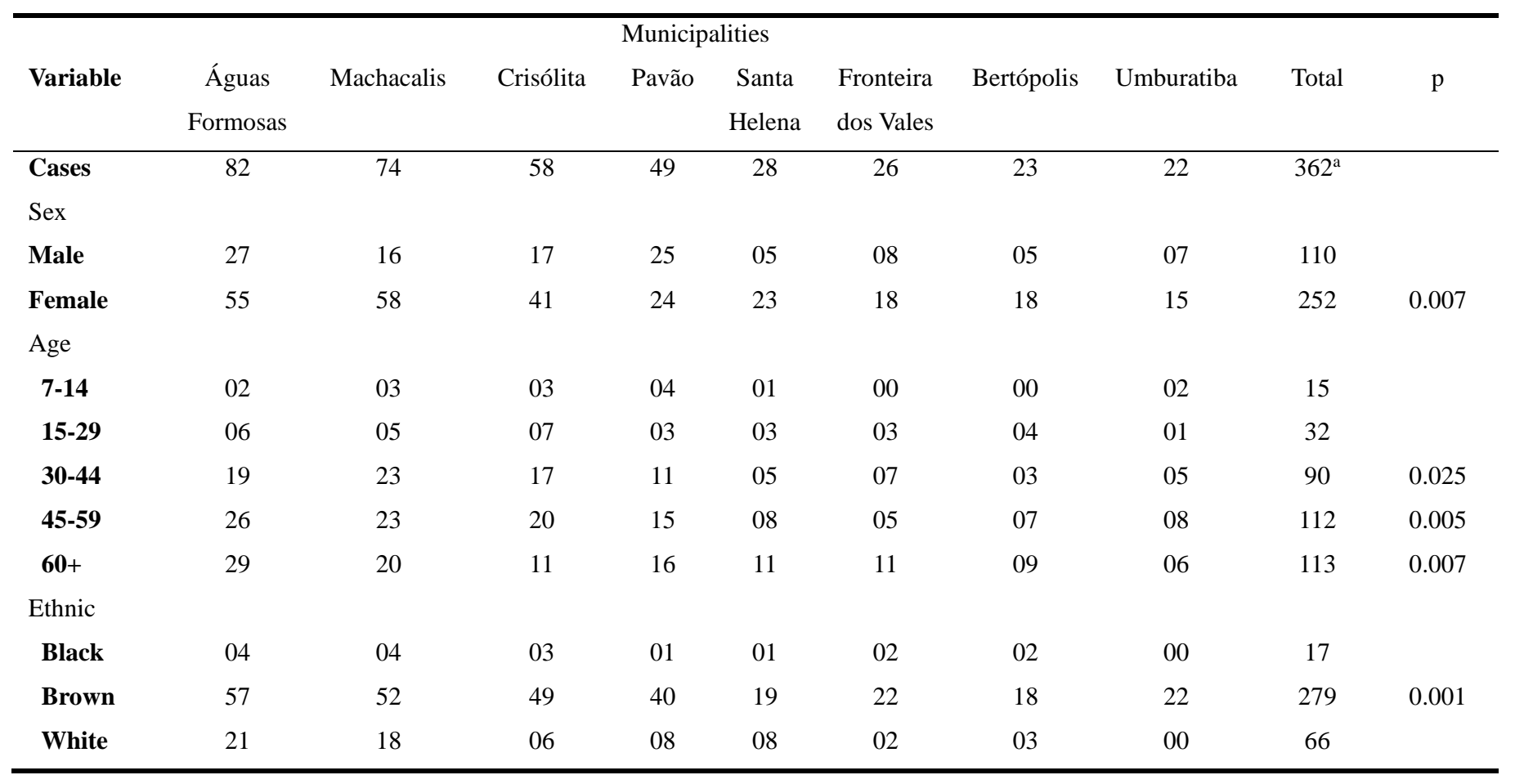

${ }^{a}$ From the 407 cases of autoimmune diseases found in the microregion, 45 were lost because the individuals did not know or refused to answer all the information on the questionnaire. Source: Authors.

The autoimmune diseases of higher incidence, Hashimoto's Thyroiditis, Graves' Disease, Vitiligo, Rheumatoid Arthritis, Psoriasis, Type 1 Diabetes Mellitus and Systemic Lupus Erythematosus, represent 47\% (192 individuals) of the studied population (Fig. 1B). In these pathologies, the behavioral variables: vaccinated against Hepatitis B; having practiced physical activity; have performed any surgical or dental procedure; have consumed mine or treated water; have consumed cow's milk in the first months of life; among others, presented influences to favor or protect the development of autoimmune diseases (Table 2). It is emphasized that some data were lost because the individuals did not know or refused to answer all the information on the questionnaire. 
Table 2. Evaluation of the variables that predisposes or protect the development of autoimmune diseases.

\begin{tabular}{|c|c|c|c|}
\hline Disease / Variable & $\mathbf{P}$ & $\begin{array}{c}\text { Adjusted Odds } \\
\text { Ratio }\end{array}$ & IC 95\% \\
\hline \multicolumn{4}{|l|}{ Grave's disease } \\
\hline Was vaccinated against hepatitis B & 0.0004 & 11.9977 & $3.04-49.55$ \\
\hline Realized odontological surgical procedure & 0.0451 & 0.1728 & $0.02-0.96$ \\
\hline \multicolumn{4}{|l|}{ Vitiligo } \\
\hline Had physical or psychological trauma & 0.0074 & 5.9848 & $1.62-22.16$ \\
\hline Was vaccinated against hepatitis B & 0.0001 & 10.2041 & $5.80-43.56$ \\
\hline Realized surgical procedures & 0.0394 & 0.2848 & $0.09-0.94$ \\
\hline Realized odontological surgical procedure & 0.0025 & 0.2691 & $0.04-0.51$ \\
\hline Used hair tints or chemicals & 0.0152 & 0.7142 & $0.11-0.79$ \\
\hline Consumed treated water & 0.0009 & 0.3325 & $0.05-0.46$ \\
\hline Practiced physical exercises & 0.0152 & 0.4904 & $0.15-0.82$ \\
\hline \multicolumn{4}{|l|}{ Rheumatoid Arthritis } \\
\hline Was vaccinated against hepatitis B & 0.0254 & 4.5422 & $1.94-14.31$ \\
\hline Consumed cow milk before 6 months of age & 0.0156 & 0.2880 & $0.08-0.77$ \\
\hline Practiced physical exercises & 0.0006 & 0.2102 & $0.06-0.64$ \\
\hline Used hair tints or chemicals & 0.0009 & 0.1405 & $0.04-0.62$ \\
\hline \multicolumn{4}{|l|}{ Psoriasis } \\
\hline Was vaccinated against hepatitis B & 0.0340 & 2.3509 & $1.11-13.47$ \\
\hline Consumed cow milk before 6 months of age & 0.0494 & 0.3321 & $0.09-0.99$ \\
\hline Realized odontological surgical procedure & 0.0170 & 0.1592 & $0.02-0.69$ \\
\hline Practiced physical exercises & 0.0010 & 0.4050 & $0.09-0.72$ \\
\hline Realized surgical procedures & 0.0415 & 0.2657 & $0.08-0.95$ \\
\hline Used hair tints or chemicals & 0.0251 & 0.2779 & $0.06-0.83$ \\
\hline \multicolumn{4}{|l|}{ Lupus } \\
\hline Was vaccinated against hepatitis B & 0.0001 & 7.7518 & $4.41-35.00$ \\
\hline Practiced physical exercises & 0.0001 & 0.0047 & $0.06-0.37$ \\
\hline Inhaled chemical solvents & 0.0483 & 0.2210 & $0.04-0.99$ \\
\hline \multicolumn{4}{|l|}{ Hashimoto's disease } \\
\hline Was vaccinated against hepatitis B & 0.0001 & 8.1969 & $4.41-35.00$ \\
\hline Practiced physical exercises & 0.0001 & 0.3133 & $0.06-0.37$ \\
\hline Inhaled chemical solvents & 0.0483 & 0.2303 & $0.04-0.99$ \\
\hline \multicolumn{4}{|l|}{ Diabetes Mellitus type 1} \\
\hline Realized surgical procedures & 0.0209 & 0.0883 & $0.01-0.68$ \\
\hline Realized odontological surgical procedure & 0.0290 & 0.1160 & $0.01-0.78$ \\
\hline
\end{tabular}




\section{Discussion}

The research was carried out in the public health system of the Microregion of Águas Formosas, belonging to the Northeast Macroregion of Minas Gerais state, one of the regions of greater social vulnerability in Brazil, known due to its low social indicators and also to exhibit characteristics of the Northeastern region of Brazil, as long drought period, high levels of poverty, malnutrition, mortality, illiteracy, unemployment, and precarious socioeconomic and political infrastructure (Ribeiro \& Galizoni, 2002). In this microregion, there are few official epidemiological data on the incidence and prevalence of autoimmune diseases, being the present study, the only one so far to carry out the survey and the respective prevalence of these pathologies.

Analyzing the obtained data, the overall female / male ratio were 2.3:1, approaching to previous studies which stated that women have a 2.7 times higher risk than men to develop an autoimmune disease and 78\% of these pathologies are more common in women according to other studies (Cutolo et al., 2006; Gleicher \& Barad, 2007; Quintero et al., 2012). The male immune system may have benefited from the hormonal characteristic in which its phenotype has low levels of estrogen and prolactin, high levels of androgens and cyclic levels of growth hormone.

In addition, the high prevalence in individuals of productive age is also corroborated by previous studies that portray that autoimmune diseases can occur at any age, from childhood to advanced age (Amador-Patarroyo et al., 2012). When assessing the onset of the various autoimmune diseases in the patient's age, it is observed that there is a variation according to each autoimmune disease. Juvenile idiopathic arthritis and Type 1 diabetes mellitus are diseases that manifest in childhood; the Systemic Lupus Erythematosus is more frequent in young people, and multiple sclerosis is more common in adulthood (Amador-Patarroyo et al., 2012).

When analyzed the behavioral factors, studies already shown that cow's milk protein intake is associated with progression of the type 1 diabetes in childhood (Lamb et al., 2015). In addition, viral infections are triggers for autoimmune diseases by various mechanisms, including direct cytolysis of virus-infected cells, cellular mimicry, and imbalance between regulatory T cells and autoreactive T cells (Pordeus et al., 2008). Also, studies have shown that the vaccination would lead to autoimmune diseases, especially Rheumatoid Arthritis (Doria et al., 2008; Guimarães et al., 2015; Toussirot \& Bereau, 2015). In this study, it was observed that in Rheumatoid Arthritis, Grave's Disease, Psoriasis, Lupus, Hashimoto's disease, and Vitiligo, the fact of having been vaccinated against Hepatitis B would tend to favor the onset of the disease.

The practice of physical activity has been shown efficiently in control of the different immunological dysfunctions. Exercise stimulates the release of anti-inflammatory compounds as cortisol and adrenaline and suppresses the release of proinflammatory cytokines (Codella et al., 2015). In the present study, physical exercise was a protective factor for the development of Hashimoto's disease, Vitiligo, Rheumatoid Arthritis, Psoriasis and Systemic Lupus Erythematosus.

\section{Conclusion}

This is one of the first studies that address more broadly the prevalence of autoimmune diseases in the microregion. Many obstacles such as lack of registration or diagnosis are factors that need to be overcome so that new studies can be carried out improving the knowledge of autoimmune diseases in this region of Águas Formosas.

As future perspectives, is suggested to elucidate the behave of the immune response in this particular population, its correlation with the regional environmental factors and its role in the prognosis of the diseases.

\section{Acknowledgments}

This work was supported in part by Fundação de Amparo à Pesquisa do Estado de Minas Gerais [grant number MPR00262-16]. The authors deny any conflicts of interest. 


\section{References}

Amador-Patarroyo, M. J.; Rodriguez-Rodriguez, A. \& Montoya-Ortiz, G. (2012). How does age at onset influence the outcome of autoimmune diseases? Autoimmune diseases, 2012, 251730.

Bogdanos, D. P.; Smyk, D. S.; Rigopoulou, E. I.; Mytilinaiou, M. G.; Heneghan, M. A.; Selmi, C. \& Gershwin, M.E. (2012). Twin studies in autoimmune disease: genetics, gender and environment. Journal of autoimmunity, 38 (2-3), J156-J169.

Codella, R., Luzi, L., Inverardi, L., \& Ricordi, C. (2015). The anti-inflammatory effects of exercise in the syndromic thread of diabetes and autoimmunity. European review for medical and pharmacological sciences, 19 (19), 3709-3722.

Cooper, G. S., \& Stroehla, B. C. (2003). The epidemiology of autoimmune diseases. Autoimmunity reviews, 2(3), 119-125.

Correa, E., Paredes, V., \& Martínez, B. (2016). Prevalence of multiple sclerosis in Latin America and its relationship with European migration. Multiple sclerosis journal - experimental, translational and clinical, 2, 2055217316666407.

Costa, C. C. B.; Medeiros, M.; Watanabe, K.; Martin, P. \& Skare, T. L. (2014). Tireoidite de Hashimoto pode estar associada a um subgrupo de pacientes de esclerose sistêmica com hipertensão pulmonar. Revista Brasileira de Reumatologia, 54 (5), 366-370.

Cutolo, M., Capellino, S., Sulli, A., Serioli, B., Secchi, M. E., Villaggio, B., \& Straub, R. H. (2006). Estrogens and autoimmune diseases. Annals of the New York Academy of Sciences, 1089, 538-547.

Doria, A., Zampieri, S., \& Sarzi-Puttini, P. (2008). Exploring the complex relationships between infections and autoimmunity. Autoimmunity reviews, 8 (2), 89-91.

Gleicher, N., \& Barad, D. H. (2007). Gender as risk factor for autoimmune diseases. Journal of autoimmunity, 28 (1), 1-6.

Guimarães, L. E., Baker, B., Perricone, C., \& Shoenfeld, Y. (2015). Vaccines, adjuvants and autoimmunity. Pharmacological research, 100, $190-209$.

Horimoto, A. M. C.; Silveira, A. F. C. \& Costa, I. P. (2016). Autoimunidade familial e poliautoimunidade em 60 pacientes portadores de esclerose sistêmica da região Centro-Oeste do Brasil. Revista Brasileira de Reumatologia, 56 (4), 314-322.

IBGE (2016). Cidades Minas Gerais. Brasil https://cidades.ibge.gov.br

Jackson, Y., Pula, D., Finckh, A., Chizzolini, C., \& Chappuis, F. (2018). Chagas disease and systemic autoimmune diseases among Bolivian patients in Switzerland. Memorias do Instituto Oswaldo Cruz, 113 (4), e170383.

Jacobson, D. L., Gange, S. J., Rose, N. R., \& Graham, N. M. (1997). Epidemiology and estimated population burden of selected autoimmune diseases in the United States. Clinical immunology and immunopathology, 84 (3), 223-243.

Khan, M. F., \& Wang, H. (2020). Environmental Exposures and Autoimmune Diseases: Contribution of Gut Microbiome. Frontiers in immunology, $10,3094$.

Koche, J. C. (2011). Fundamentos de metodologia científica. Vozes

Krawczak, K., Donskow-Łysoniewska, K., \& Doligalska, M. (2017). Regulatory function of parasites in autoimmune disease - outcome from experimental model infection. Annals of parasitology, 63 (1), 7-14.

Lamb, M. M.; Miller, M.; Seifert, J. A.; Frederiksen, B.; Kroehl, M.; Rewers, M. \& Norris, J. M. (2015). The effect of childhood cow's milk intake and HLADR genotype on risk of islet autoimmunity and type 1 diabetes: the Diabetes Autoimmunity Study in the Young. Pediatric diabetes, 16 (1), 31-38.

Ludke, M. \& Andre, M. E. D. A. (2013). Pesquisas em educação: uma abordagem qualitativa. E.P.U.

Mak, A., \& Tay, S. H. (2014). Environmental factors, toxicants and systemic lupus erythematosus. International journal of molecular sciences, 15(9), 1604316056.

Milo, R., \& Kahana, E. (2010). Multiple sclerosis: geoepidemiology, genetics and the environment. Autoimmunity reviews, 9(5), A387-A394.

Moroni, L., Bianchi, I., \& Lleo, A. (2012). Geoepidemiology, gender and autoimmune disease. Autoimmunity reviews, 11 (6-7), A386-A392.

Pordeus, V., Szyper-Kravitz, M., Levy, R. A., Vaz, N. M., \& Shoenfeld, Y. (2008). Infections and autoimmunity: a panorama. Clinical reviews in allergy \& immunology, 34 (3), 283-299.

Quintero, O. L., Amador-Patarroyo, M. J., Montoya-Ortiz, G., Rojas-Villarraga, A., \& Anaya, J. M. (2012). Autoimmune disease and gender: plausible mechanisms for the female predominance of autoimmunity. Journal of autoimmunity, 38 (2-3), J109-J119.

Ribeiro, E. M. \& Galizoni, F. M. (2002). Água, população rural e políticas de gestão: o caso do vale do Jequitinhonha, Minas Gerais. Ambiente \& Sociedade, 5 (2), 129-146.

Roberts, M. H., \& Erdei, E. (2020). Comparative United States autoimmune disease rates for 2010-2016 by sex, geographic region, and race. Autoimmunity reviews, 19 (1), 102423.

Rose N. R. (2017). Negative selection, epitope mimicry and autoimmunity. Current opinion in immunology, 49, 51-55.

Shukla, S. K., Singh, G., Ahmad, S., \& Pant, P. (2018). Infections, genetic and environmental factors in pathogenesis of autoimmune thyroid diseases. Microbial pathogenesis, 116, 279-288. 
Research, Society and Development, v. 10, n. 4, e29910414138, 2021

(CC BY 4.0) | ISSN 2525-3409 | DOI: http://dx.doi.org/10.33448/rsd-v10i4.14138

Toussirot, É., \& Bereau, M. (2015). Vaccination and Induction of Autoimmune Diseases. Inflammation \& allergy drug targets, 14 (2), $94-98$.

Ulmanen, I., Halonen, M., Ilmarinen, T., \& Peltonen, L. (2005). Monogenic autoimmune diseases - lessons of self-tolerance. Current opinion in immunology, 17(6), 609-615.

Wahren-Herlenius, M., \& Dörner, T. (2013). Immunopathogenic mechanisms of systemic autoimmune disease. Lancet (London, England), 382 (9894), 819831.

Yang, S. H., Gao, C. Y., Li, L., Chang, C., Leung, P., Gershwin, M. E., \& Lian, Z. X. (2018). The molecular basis of immune regulation in autoimmunity. Clinical science (London, England: 1979), 132 (1), 43-67.

Yin, R. K. (2015). O estudo de caso. Bookman.

Zangirolami-Raimundo, J., Echeimberg, J. O., \& Leone, C. (2018). Research methodology topics: Cross-sectional studies. Journal of Human Growth and Development, 28(3), 356-360. 